\title{
Article
}

\section{Intercultural Differences in the Perception of HVAC Sound Quality in Car Cabins: From Conventional to Electric Vehicles}

\author{
Massimiliano Masullo ${ }^{1, *(\mathbb{D})}$, Katsuya Yamauchi ${ }^{2} \mathbb{D}$, Minori Dan ${ }^{2}$, Federico Cioffi ${ }^{1}$ and $^{\text {Luigi Maffei }}{ }^{1} \mathbb{D}$ \\ 1 Department of Architecture and Industrial Design, Università degli Studi della Campania "Luigi Vanvitelli", \\ 81031 Aversa, Italy; federico.cioffi@unicampania.it (F.C.); luigi.maffei@unicampania.it (L.M.) \\ 2 Department of Communication Design Science, Kyushu University, Shiobaru 4-9-1, Fukuoka 815-8540, Japan; \\ yamauchi@design.kyushu-u.ac.jp (K.Y.); dan.minori.111@s.kyushu-u.ac.jp (M.D.) \\ * Correspondence: massimiliano.masullo@unicampania.it
}

Citation: Masullo, M.; Yamauchi, K.; Dan, M.; Cioffi, F.; Maffei, L.

Intercultural Differences in the Perception of HVAC Sound Quality in Car Cabins: From Conventional to Electric Vehicles. Appl. Sci. 2021, 11, 11431. https://doi.org/10.3390/ app112311431

Academic Editor: Yon-Do Chun

Received: 10 November 2021 Accepted: 29 November 2021 Published: 2 December 2021

Publisher's Note: MDPI stays neutral with regard to jurisdictional claims in published maps and institutional affiliations.

Copyright: (c) 2021 by the authors. Licensee MDPI, Basel, Switzerland. This article is an open access article distributed under the terms and conditions of the Creative Commons Attribution (CC BY) license (https:/ / creativecommons.org/licenses/by/ $4.0 /)$.

\begin{abstract}
In electric-powered cars, the production of which is increasing, the HVAC system is responsible for most of the noise inside the car's cabin, causing significant discomfort for passengers. Moreover, the noise produced by the HVAC affects the perceptible sound inside the car cabin, significantly impacting the perceived quality of the vehicle. It is thus essential to investigate and quantify people's preferences concerning HVAC noise. Our previous research revealed differences in the HVAC noise between hybrid electric (HEV) and internal combustion engine (ICEV) vehicles. A subsequent factor analysis revealed that the adjectives used to describe the sounds can be grouped into two main dimensions: Aesthetic and Loudness. The present paper highlights the results of a listening test that aimed to identify possible differences in the perception of HVACs' sound quality between Italian and Japanese subject groups, for ICEV and HEV, in different functioning conditions. Results revealed that the most remarkable difference emerges at high air flow rates, where the Japanese group perceived the quality of sound and annoyance, respectively, to be significantly lower and significantly higher than the Italian group.
\end{abstract}

Keywords: electric vehicles; internal combustion engine vehicles; HVAC; sound quality; automotive

\section{Introduction}

Car users have become increasingly demanding [1,2], asking for higher sound quality levels inside vehicles' cabins. Sound quality consists of a perceptual reaction to the sound of a product that reflects the listener's reaction to the acceptability of that sound; the more the sound is considered to be acceptable, the greater the sound quality [3,4]. However, having low-level sound does not necessarily mean having high sound quality [5]. To investigate the complexity of sound quality perception inside vehicles, several authors have developed models and metrics that consider the different aspects of perceptual dimensions [6-10].

Heating, Ventilation, and Air Conditioning (HVAC) systems are fundamental to set and maintain the microclimatic conditions inside a car's cabin or its portions, providing optimal thermal comfort for occupants. Nevertheless, these systems represent one of the most annoying noise sources for drivers and passengers. This is particularly true in idling conditions, at low speed of Internal Combustion Engine Vehicles (ICEV) and, at low engine rpms.

HVAC noise is produced by the fan rotation and airflow interactions passing through the different plant components (e.g., outlets, thermal exchangers, and ducts) [11]; consequently, this noise is generated not far from the receiver's positions of drivers and passengers. This has focused the attention of the automotive industry to propose different noise reduction design measures on moving all or part of the HVAC system into the engine compartment or using passive acoustics absorbers on the propagation path [12] to improve the acoustic and thermal comfort $[13,14]$. 
As a result of the increasing number of hybrid electric vehicles (HEVs) [15], the character of noise inside cabins has significantly changed [16]. Graham-Rowe et al. [17] found that the lack of engine noise when using electric vehicles leads many drivers to experience pleasant driving. However, this is not the only reaction. Because customers accept or at times even expect and wish for operational feedback in certain situations while driving electric, some drivers consider the acoustic feedback of car inadequate $[18,19]$. For Krishna this can be associated with the culture of cars [20]. Previous research regarding nationality or culture found that sound preferences of door sounds were similar between German and Japanese participants [21], but differences were revealed between Americans and West Europeans in an evaluation of the vehicle interior sound during driving [22].

Due to the lack of the ICEV engine noise, the background noise in HEVs has been dramatically reduced by up to $9 \mathrm{~dB}$ [16]. As a result, the role of the HVAC noise on the perceived sound quality in cars' cabins is becoming more crucial.

This paper presents the results of an intermediate step of the "Collaborative Research Project on HVAC sound quality inside cars cabins" between the Department of Architecture and Industrial Design of the Università degli Studi della Campania "Luigi Vanvitelli" and the Department of Communication Design Science, Faculty of Design, Kyushu University. In this phase of the project, some of the previously collected binaural recordings were used to investigate, in two parallel listening tests in Italy and Japan $[23,24]$, the possible differences in sound quality perceptions between two types of engines in Italian and Japanese populations.

\section{Materials and Methods}

\subsection{Materials}

\subsubsection{Audio Material}

The recordings were of two groups of vehicles, ICEVs and HEVs. In total, 20 units were measured-in Japan, 8 HEVs and 2 ICEVs, whereas in Italy 2 HEVs and 8 ICEVs. In all cases, HVAC noise was measured at the front-left seat inside each vehicle, i.e., the driver position in Italy, the passenger position in Japan. The background noise inside the vehicles was less than $35 \mathrm{~dB}$ in the equivalent continuous A-weighted sound pressure level $\left(L_{\mathrm{Aeq}}\right)$. Measurements were carried out with a 4-channel measuring system. This consisted of a SQobold, a binaural headset (Head Acoustics/BHS II) positioned on a Mk2 Cortex manikin in Italy; and a 2-channel head and torso simulator (HATS Type 4100, Brüel \& Kjær), in Japan. The playback sound pressure level was calibrated using, respectively, a binaural Mk2 Cortex manikin, and a head and torso simulator HATS. The position of the right microphone of the HATS/BHS II was approximately $0.80 \mathrm{~m}$ from the closest central outlet and about $0.70 \mathrm{~m}$ above the seat. During the measurements, all the windows and doors were kept closed, and all the air outlet valves were fully opened and slightly oriented to the floor to prevent noise induced by airflow on the microphones. Recordings were made compatible using a comparative measurement carried out at the Kyushu University and by developing equalizer filters. Each recording lasted $30 \mathrm{~s}$ and considered different Function Modalities (FMs), Air Outlets (AOs), and Air Flow Rates (AFRs) [4]. Sections having a length of $5 \mathrm{~s}$ were analyzed by the software (Artemis Suite, Head Acoustics) to extract representative audio samples. To avoid a click noise, $60 \mathrm{~ms}$ fade-in and $80 \mathrm{~ms}$ fade-out were processed for each stimulus. The excerpts were then grouped into two Functional Modalities (Ventilation and Air-Conditioning) and Engine Types (ICEV and HEV) as shown below:

- VE: Ventilation driven by Internal Combustion Engine;

- $\quad$ AC: Air Conditioning driven by Internal Combustion Engine;

- EVE: Ventilation driven by Electric Engine;

- EAC: Air Conditioning driven by Electric Engine.

Concerning the Air Outlets, only the frontal one was considered because it represents the most common and frequently used. Furthermore, concerning the Air Flow Rates, four AFRs were considered, when the ventilation power was at $25 \%, 50 \%, 75 \%$ and $100 \%$. 
Finally, the collected samples were compared, and those within one standard deviation on the A-weighted sound pressure level were chosen. In total, 48 HVAC samples were used in the experiment-2 FM $\times 4$ AFR for each test vehicle, i.e., 3 ICEVs +3 HEVs.

\subsubsection{Subjective Questionnaire}

Participants were asked to rate their impression of each stimulus on a 7-point semantic differential scale of 14 adjective pairs, which explored different aspects of sound: Quality, Pleasantness, Power, Spatio-temporal, and Spectral structure [25-28]. The scales were originally collected in English, then the translated versions, in Japanese and Italian, were used in the experiments (Table 1 ).

Table 1. Semantic Differential Scale.

\begin{tabular}{|c|c|c|}
\hline Japanese & English & Italian \\
\hline 機能している一壊れた & Functioning-Broken & Funzionante-Rotto \\
\hline 高品質な一低品質な & High Quality_Low Quality & Alta Qualità-Bassa Qualità \\
\hline 煩わしくない一煩わしい & Not Annoying-Annoying & Non Fastidioso-Fastidioso \\
\hline 自然な一機械的な & Natural-Mechanical & Naturale-Meccanico \\
\hline 不快一心地よい & Unpleasant-Pleasant & Sgradevole-Gradevole \\
\hline 騷々しい一静かな & Noisy-Quiet & Rumoroso-Quieto \\
\hline 大きい一小さい & Loud-Soft & Alto Volume-Basso Volume \\
\hline 力強い一弱々しい & Powerful-Weak & Potente-Debole \\
\hline 拡がりのある一局所的な & Diffuse-Localized & Diffuso-Localizzato \\
\hline 変動した一安定した & Fluctuating-Stable & Fluttuante-Stabile \\
\hline 粗い一滑らかな & Rough—Flat & Ruvido-Piatto \\
\hline 鋭い一鈍い & Sharp-Dull & Acuto-Grave \\
\hline 澄んだ一濁った & Clear-Thick & Chiaro-Sordo \\
\hline 広帯域性の一純音性の & Wideband-Tonal & A banda larga-Tonale \\
\hline
\end{tabular}

\subsection{Participants}

Forty volunteers participated in two parallel experiments. Twenty of them (10 males; 10 females) $\left(M_{\mathrm{age}}=22.1 ; \mathrm{SD}_{\mathrm{age}}=1.07\right)$ were enrolled in the experiment in the Japanese Subject Group, and the other 20 (13 males; 7 females) $\left(M_{\text {age }}=30.6 ; \mathrm{SD}_{\text {age }}=5.1\right)$ were enrolled in the experiment in the Italian Subject Group. All participated voluntarily, without receiving any type of compensation.

\subsection{Method}

Two parallel listening experiments were conducted to investigate the perception of the HVAC noise in car cabins. The experiments were performed in soundproof laboratories at Kyushu University and Università degli Studi della Campania "Luigi Vanvitelli". All 48 stimuli were presented to participants via an audio-interface (RME/babyface) and headphones (Sennheiser/HD650) in Japan, and via laptop and headphones (Sennheiser/HD200 PRO) in Italy. After participants received information about the study and provided informed consent, the procedure started. Participants could listen to the stimuli as many times as they wanted before proceeding to the next one. Three adjective couples most pertaining to Aesthetic and Loudness dimensions [12,16] were chosen from the experimental sessions. They are High Quality-Low Quality, Not Annoying-Annoying and Unpleasant-Pleasant for the Aesthetic dimension; and Loud-Soft, Noisy-Quiet, and Powerful-Weak, for the Loudness dimension. 


\section{Results}

To investigate possible differences between the two Subject Groups in the Aesthetic (Figure 1) and Loudness (Figure 2) dimensions, for each of the adjective couples, two repeated measures ANOVAs were conducted separately for the Ventilation and Air Conditioning Functional Modalities. The ANOVAs treated Engine Type and Air Flow Rate as within-subjects factors and the Subject Group as a between-subjects factor.
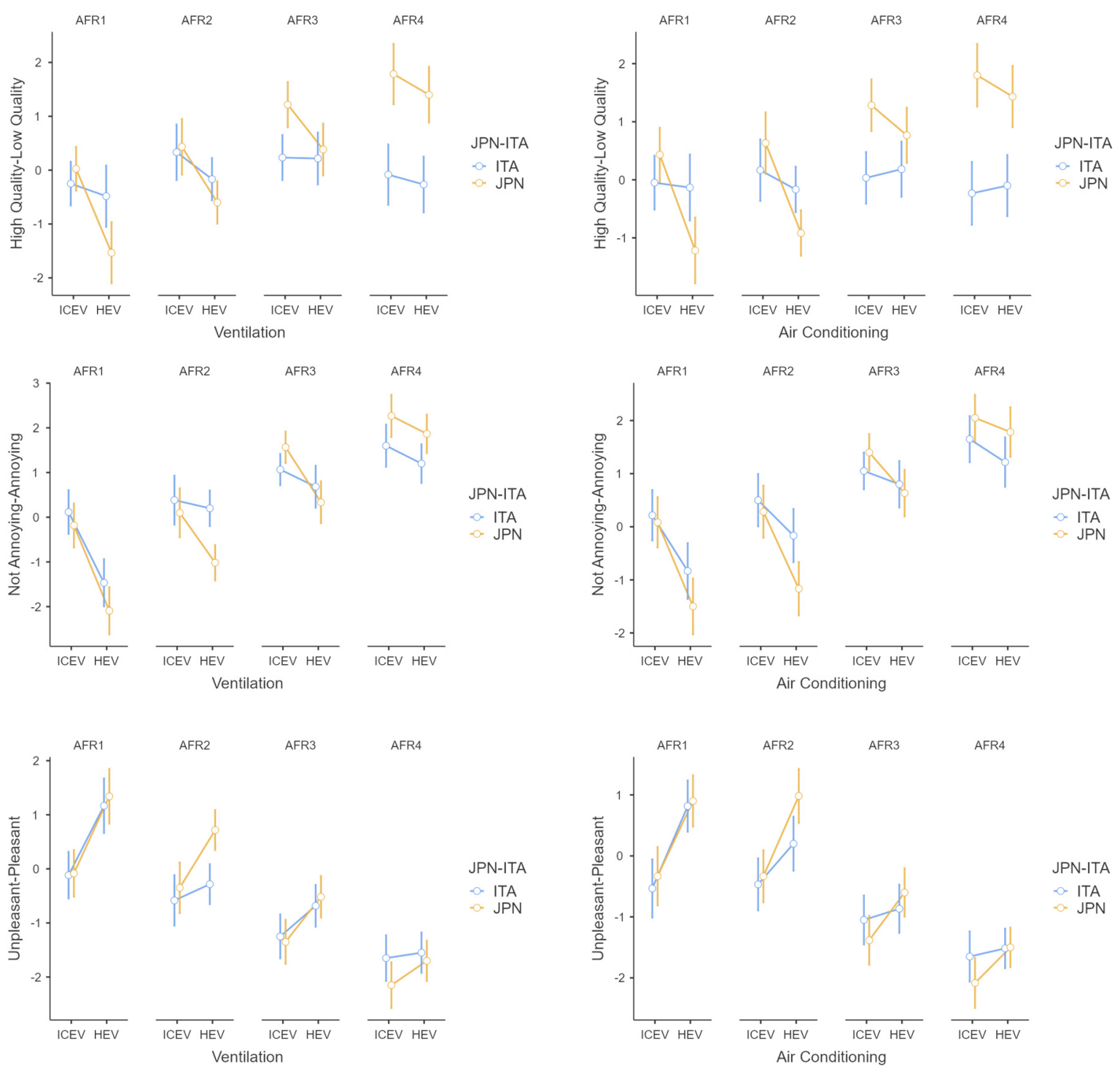

Figure 1. Marginal mean and 95\% confidence interval of the Aesthetic dimension items in the Ventilation (left) and Air Conditioning (right) Functional Modality, for different AFR, Engine Type, and Subject Group. 

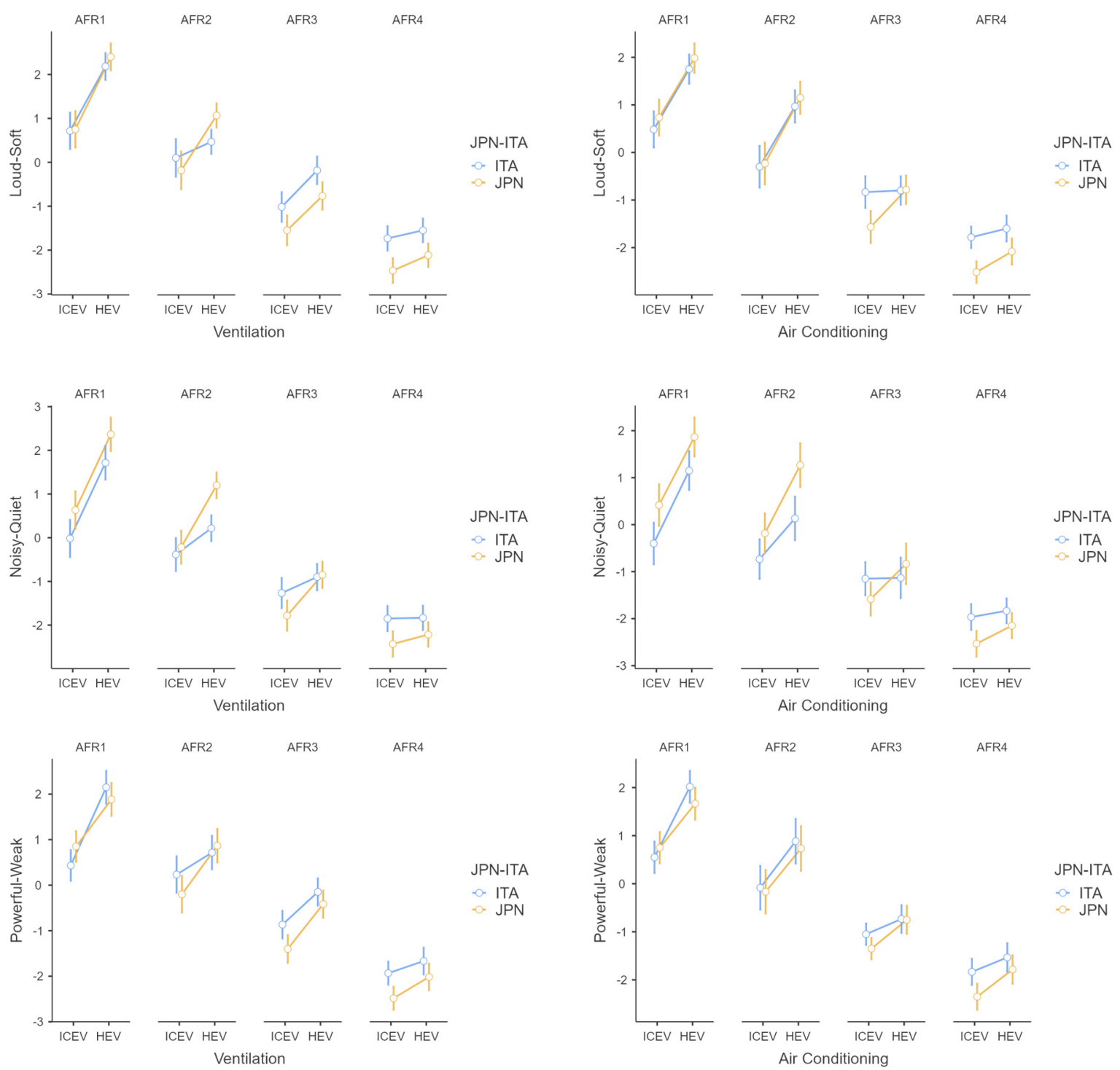

Figure 2. Marginal mean and 95\% confidence interval of the Loudness dimension items in the Ventilation (left) and Air Conditioning (right) Functional Modality, for different AFR, Engine Type, and Subject Group.

Considering the adjectives of the Aesthetic dimension, the analyses of the High QualityLow Quality (Table 2) adjective couple in both the Functional Modalities (Ventilation and Air Conditioning) showed the significance of the main effects of the Air Flow Rate, Engine Type, and Subject Group, and of the interactions between Air Flow Rate $\times$ Subject Group, Engine Type $\times$ Subject Group, and Air Flow Rate $\times$ Engine Type.

Air Flow Rate and Engine Type main effects and the interaction between Air Flow Rate $\times$ Subject Group and Air Flow Rate $\times$ Engine Type were also significant for the Not Annoying-Annoying (Table 3) and Unpleasant-Pleasant (Table 4) adjective couples in both Functional Modalities. In contrast, the interaction between Engine Type $x$ Subject Group was significant only in the Air Conditioning Functional Modality for the Unpleasant-Pleasant adjective couples. 
Table 2. ANOVA results for High Quality-Low Quality.

\begin{tabular}{|c|c|c|c|c|c|c|c|c|c|c|c|c|}
\hline \multirow{2}{*}{$\begin{array}{l}\begin{array}{c}\text { High Quality-Low } \\
\text { Quality }\end{array} \\
\text { Within Subj. Effects } \\
\end{array}$} & \multicolumn{6}{|c|}{ Ventilation } & \multicolumn{6}{|c|}{ Air Conditioning } \\
\hline & SS & df & MS & F & $p$ & $\eta_{p}^{2}$ & SS & df & MS & $\mathbf{F}$ & $p$ & $\eta_{p}^{2}$ \\
\hline AFR & 77.55 & 3 & 25.851 & 22.16 & $<0.001$ & 0.368 & 53.64 & 3 & 17.879 & 15.78 & $<0.001$ & 0.293 \\
\hline AFR $\times$ Subj. Group & 56.62 & 3 & 18.873 & 16.18 & $<0.001$ & 0.299 & 57.11 & 3 & 19.037 & 16.81 & $<0.001$ & 0.307 \\
\hline Residual & 132.98 & 114 & 1.166 & & & & 129.13 & 114 & 1.133 & & & \\
\hline Eng. Type & 28.10 & 1 & 28.104 & 34.41 & $<0.001$ & 0.475 & 22.23 & 1 & 22.225 & 25.25 & $<0.001$ & 0.399 \\
\hline $\begin{array}{l}\text { Eng. Type } \times \text { Subj. } \\
\text { Group }\end{array}$ & 10.33 & 1 & 10.332 & 12.65 & 0.001 & 0.250 & 19.50 & 1 & 19.503 & 22.15 & $<0.001$ & 0.368 \\
\hline Residual & 31.04 & 38 & 0.817 & & & & 33.45 & 38 & 0.880 & & & \\
\hline AFR × Eng. Type & 4.92 & 3 & 1.640 & 3.81 & 0.012 & 0.091 & 11.48 & 3 & 3.825 & 7.76 & $<0.001$ & 0.170 \\
\hline $\begin{array}{l}\text { AFR } \times \text { Eng. Type } \times \\
\text { Subj. Group }\end{array}$ & 3.40 & 3 & 1.134 & 2.64 & 0.053 & 0.065 & 3.64 & 3 & 1.214 & 2.46 & 0.066 & 0.061 \\
\hline Residual & 49.05 & 114 & 0.430 & & & & 56.20 & 114 & 0.493 & & & \\
\hline Between Subj. Effects & SS & $\mathrm{df}$ & MS & $\mathrm{F}$ & $p$ & $\eta^{2} p$ & SS & $\mathrm{df}$ & MS & $\mathrm{F}$ & $p$ & $\eta^{2} p$ \\
\hline $\begin{array}{l}\text { Subj. Group } \\
\text { Residual }\end{array}$ & $\begin{array}{c}16.0 \\
140.3\end{array}$ & $\begin{array}{c}1 \\
38\end{array}$ & $\begin{array}{c}15.98 \\
3.69\end{array}$ & 4.33 & 0.044 & 0.102 & $\begin{array}{c}25.5 \\
145.9\end{array}$ & 6.64 & 0.014 & 6.64 & 0.014 & 0.149 \\
\hline
\end{tabular}

Table 3. ANOVA results for Not Annoying-Annoying.

\begin{tabular}{|c|c|c|c|c|c|c|c|c|c|c|c|c|}
\hline \multirow{2}{*}{$\begin{array}{l}\text { Not } \\
\text { Annoying-Annoying } \\
\text { Within Subj. Effects } \\
\end{array}$} & \multicolumn{6}{|c|}{ Ventilation } & \multicolumn{6}{|c|}{ Air Conditioning } \\
\hline & SS & df & MS & $\mathbf{F}$ & $p$ & $\eta^{2} p$ & SS & df & MS & $\mathbf{F}$ & $p$ & $\eta^{2} p$ \\
\hline AFR & 318.36 & 3 & 106.12 & 111.07 & $<0.001$ & 0.745 & 242.04 & 3 & 80.68 & 92.81 & $<0.001$ & 0.710 \\
\hline AFR $\times$ Subj. Group & 23.42 & 3 & 7.81 & 8.17 & $<0.001$ & 0.177 & 14.50 & 3 & 4.83 & 5.56 & 0.001 & 0.128 \\
\hline Residual & 108.92 & 114 & 0.96 & & & & 99.10 & 114 & 0.87 & & & \\
\hline Eng. Type & 64.95 & 1 & 64.95 & 139.29 & $<0.001$ & 0.786 & 52.27 & 1 & 52.27 & 46.07 & $<0.001$ & 0.548 \\
\hline $\begin{array}{l}\text { Eng. Type } \times \text { Subj. } \\
\text { Group }\end{array}$ & 5.56 & 1 & 5.56 & 11.92 & 0.001 & 0.239 & 3.47 & 1 & 3.47 & 3.06 & 0.088 & 0.075 \\
\hline Residual & 17.72 & 38 & 0.47 & & & & 43.12 & 38 & 1.13 & & & \\
\hline AFR × Eng. Type & 20.73 & 3 & 6.91 & 13.31 & $<0.001$ & 0.259 & 12.42 & 3 & 4.14 & 9.09 & $<0.001$ & 0.193 \\
\hline $\begin{array}{l}\text { AFR } \times \text { Eng. Type } \times \\
\text { Subj. Group }\end{array}$ & 2.94 & 3 & 0.98 & 1.89 & 0.136 & 0.047 & 2.49 & 3 & 0.83 & 1.82 & 0.147 & 0.046 \\
\hline $\begin{array}{l}\text { Residual } \\
\text { Between Subj. Effects }\end{array}$ & $\begin{array}{l}59.18 \\
\text { SS }\end{array}$ & $\begin{array}{c}114 \\
\mathrm{df}\end{array}$ & $\begin{array}{l}0.52 \\
\text { MS }\end{array}$ & $\mathrm{F}$ & $p$ & $\eta^{2} \mathrm{p}$ & $\begin{array}{c}51.89 \\
\text { SS }\end{array}$ & $\begin{array}{c}114 \\
\mathrm{df}\end{array}$ & $\begin{array}{l}0.46 \\
\text { MS }\end{array}$ & $\mathrm{F}$ & $p$ & $\eta^{2} \mathrm{p}$ \\
\hline Subj. Group & 1.11 & 1 & 1.11 & 0.31 & 0.580 & 0.008 & 0.94 & 1 & 0.94 & 0.287 & 0.595 & 0.008 \\
\hline Residual & 135.50 & 38 & 3.57 & & & & 124.20 & 38 & 3.27 & & & \\
\hline
\end{tabular}

Table 4. ANOVA results for Unpleasant-Pleasant.

\begin{tabular}{|c|c|c|c|c|c|c|c|c|c|c|c|c|}
\hline \multirow{2}{*}{$\begin{array}{l}\text { Unpleasant-Pleasant } \\
\text { Within Subj. Effects }\end{array}$} & \multicolumn{6}{|c|}{ Ventilation } & \multicolumn{6}{|c|}{ Air Conditioning } \\
\hline & SS & df & MS & F & $p$ & $\eta^{2} p$ & SS & df & MS & F & $p$ & $\eta^{2} p$ \\
\hline AFR & 246.41 & 3 & 82.14 & 115.12 & $<0.001$ & 0.752 & 197.37 & 3 & 65.789 & 110.09 & $<0.001$ & 0.743 \\
\hline AFR $\times$ Subj. Group & 9.04 & 3 & 3.01 & 4.22 & 0.007 & 0.100 & 4.85 & 3 & 1.617 & 2.71 & 0.049 & 0.066 \\
\hline Residual & 81.34 & 114 & 0.71 & & & & 68.13 & 114 & 0.598 & & & \\
\hline Eng. Type & 45.38 & 1 & 45.38 & 88.06 & $<0.001$ & 0.699 & 48.83 & 1 & 48.828 & 57.64 & $<0.001$ & 0.603 \\
\hline $\begin{array}{l}\text { Eng. Type } \times \text { Subj. } \\
\text { Group }\end{array}$ & 2.91 & 1 & 2.91 & 5.64 & 0.023 & 0.129 & 3.13 & 1 & 3.134 & 3.70 & 0.062 & 0.089 \\
\hline Residual & 19.58 & 38 & 0.52 & & & & 32.19 & 38 & 0.847 & & & \\
\hline AFR × Eng. Type & 11.95 & 3 & 3.98 & 10.0 & $<0.001$ & 0.208 & 11.45 & 3 & 3.816 & 10.38 & $<0.001$ & 0.214 \\
\hline $\begin{array}{l}\text { AFR } \times \text { Eng. Type } \times \\
\text { Subj. Group }\end{array}$ & 1.10 & 3 & 0.37 & 0.92 & 0.433 & 0.024 & 1.86 & 3 & 0.620 & 1.69 & 0.174 & 0.042 \\
\hline Residual & 45.43 & 114 & 0.40 & & & & 41.93 & 114 & 0.368 & & & \\
\hline Between Subj. Effects & SS & $\mathrm{df}$ & MS & $\mathrm{F}$ & $p$ & $\eta^{2} p$ & SS & $\mathrm{df}$ & MS & $\mathrm{F}$ & $p$ & $\eta^{2} p$ \\
\hline Subj. Group & 0.921 & 1 & 0.92 & 0.29 & 0.592 & 0.008 & 0.642 & 1 & 0.642 & 0.216 & 0.001 & 0.006 \\
\hline Residual & 119.560 & 38 & 3.15 & & & & 113.11 & 38 & 2.977 & & & \\
\hline
\end{tabular}

Marginal means of the previous three adjective couples describing the Aesthetic dimension as a function of the Engine Type and Air Flow Rate are shown in Figure 1. Different graphs are shown for the Ventilation and Air Conditioning Functional Modality. 
The ANOVAs on the adjectives of the Loudness dimension revealed the significance of the main effects of the Air Flow Rate and Engine, and of the interactions between Air Flow Rate $\times$ Subject Group and Air Flow Rate $\times$ Engine Type of the Loud-Soft (Table 5) and Noisy-Quiet (Table 6) in both the Functional Modalities. Interaction between Engine Type $\times$ Subject Group was significant only in the Air Conditioning Functional Modality for NoisyQuiet. Air Flow Rate and Engine Type were significant main effects for the Powerful-Weak (Table 7) adjective couple, in addition to the interaction Air Flow Rate $\times$ Engine Type. The interactions Air Flow Rate $\times$ Engine Type $\times$ Subject Group were significant only for the Ventilation Functional Modality.

Table 5. ANOVA results for Loud-Soft.

\begin{tabular}{|c|c|c|c|c|c|c|c|c|c|c|c|c|}
\hline \multirow{2}{*}{$\begin{array}{c}\text { Loud-Soft } \\
\text { Within Subj. Effects }\end{array}$} & \multicolumn{6}{|c|}{ Ventilation } & \multicolumn{6}{|c|}{ Air Conditioning } \\
\hline & SS & df & MS & $\mathbf{F}$ & $p$ & $\eta^{2} p$ & SS & df & MS & $\mathbf{F}$ & $p$ & $\eta^{2} p$ \\
\hline AFR & 545.93 & 3 & 181.98 & 388.36 & $<0.001$ & 0.911 & 496.15 & 3 & 165.38 & 388.46 & $<0.001$ & 0.911 \\
\hline AFR $\times$ Subj. Group & 11.22 & 3 & 3.74 & 7.98 & $<0.001$ & 0.174 & 9.65 & 3 & 3.22 & 7.56 & $<0.001$ & 0.166 \\
\hline Residual & 53.42 & 114 & 0.47 & & & & 48.53 & 114 & 0.43 & & & \\
\hline Eng. Type & 59.23 & 1 & 59.23 & 108.26 & $<0.001$ & 0.740 & 54.45 & 1 & 54.45 & 79.98 & $<0.001$ & 0.678 \\
\hline $\begin{array}{l}\text { Eng. Type } \times \text { Subj. } \\
\text { Group }\end{array}$ & 1.75 & 1 & 1.75 & 3.20 & 0.082 & 0.078 & 1.51 & 1 & 1.51 & 2.22 & 0.144 & 0.055 \\
\hline Residual & 20.79 & 38 & 0.55 & & & & 25.87 & 38 & 0.68 & & & \\
\hline AFR × Eng. Type & 16.90 & 3 & 5.63 & 16.32 & $<0.001$ & 0.300 & 17.57 & 3 & 5.86 & 17.76 & $<0.001$ & 0.319 \\
\hline $\begin{array}{l}\text { AFR } \times \text { Eng. Type } \times \\
\text { Subj. Group }\end{array}$ & 2.47 & 3 & 0.82 & 2.38 & 0.073 & 0.059 & 1.68 & 3 & 0.56 & 1.70 & 0.171 & 0.043 \\
\hline Residual & 39.36 & 114 & 0.35 & & & & 37.58 & 114 & 0.33 & & & \\
\hline Between Subj. Effects & SS & $\mathrm{df}$ & MS & $\mathrm{F}$ & $p$ & $\eta^{2} p$ & SS & $\mathrm{df}$ & MS & $\mathrm{F}$ & $p$ & $\eta_{p}^{2}$ \\
\hline Subj. Group & 4.28 & 1 & 4.28 & 3.08 & 0.087 & 0.075 & 1.80 & 1 & 1.80 & 1.36 & 0.251 & 0.035 \\
\hline Residual & 52.80 & 38 & 1.39 & & & & 50.30 & 38 & 1.32 & & & \\
\hline
\end{tabular}

Table 6. ANOVA results for Noisy-Quiet.

\begin{tabular}{|c|c|c|c|c|c|c|c|c|c|c|c|c|}
\hline \multirow{2}{*}{$\begin{array}{c}\text { Noisy-Quiet } \\
\text { Within Subj. Effects }\end{array}$} & \multicolumn{6}{|c|}{ Ventilation } & \multicolumn{6}{|c|}{ Air Conditioning } \\
\hline & SS & df & MS & $\mathbf{F}$ & $p$ & $\eta^{2} p$ & SS & df & MS & $\mathbf{F}$ & $p$ & $\eta^{2} p$ \\
\hline AFR & 503.69 & 3 & 167.90 & 322.81 & $<0.001$ & 0.895 & 400.65 & 3 & 133.55 & 195.37 & $<0.001$ & 0.837 \\
\hline AFR $\times$ Subj. Group & 19.53 & 3 & 6.51 & 12.52 & $<0.001$ & 0.248 & 23.86 & 3 & 7.96 & 11.64 & $<0.001$ & 0.234 \\
\hline Residual & 59.29 & 114 & 0.52 & & & & 77.93 & 114 & 0.68 & & & \\
\hline Eng. Type & 61.54 & 1 & 61.54 & 143.38 & $<0.001$ & 0.790 & 54.45 & 1 & 54.45 & 77.51 & $<0.001$ & 0.671 \\
\hline $\begin{array}{l}\text { Eng. Type } \times \text { Subj. } \\
\text { Group }\end{array}$ & 3.13 & 1 & 3.13 & 7.30 & 0.010 & 0.161 & 2.69 & 1 & 2.69 & 3.83 & 0.058 & 0.092 \\
\hline Residual & 16.31 & 38 & 0.43 & & & & 26.69 & 38 & 0.70 & & & \\
\hline AFR $\times$ Eng. Type & 27.60 & 3 & 9.20 & 26.14 & $<0.001$ & 0.408 & 21.66 & 3 & 7.22 & 19.24 & $<0.001$ & 0.336 \\
\hline $\begin{array}{l}\text { AFR } \times \text { Eng. Type } \times \\
\text { Subj. Group }\end{array}$ & 2.01 & 3 & 0.67 & 1.90 & 0.134 & 0.048 & 2.06 & 3 & 0.69 & 1.83 & 0.145 & 0.046 \\
\hline Residual & 40.13 & 114 & 0.35 & & & & 42.78 & 114 & 0.37 & & & \\
\hline Between Subj. Effects & SS & $\mathrm{df}$ & MS & $\mathrm{F}$ & $p$ & $\eta^{2} p$ & SS & $\mathrm{df}$ & MS & $\mathrm{F}$ & $p$ & $\eta^{2} p$ \\
\hline Subj. Group & 1.29 & 1 & 1.29 & 0.84 & 0.365 & 0.022 & 6.05 & 1 & 6.05 & 2.91 & 0.096 & 0.071 \\
\hline Residual & 58.40 & 38 & 1.54 & & & & 79.03 & 38 & 2.08 & & & \\
\hline
\end{tabular}


Table 7. ANOVA results for Powerful-Weak.

\begin{tabular}{|c|c|c|c|c|c|c|c|c|c|c|c|c|}
\hline \multirow{2}{*}{$\begin{array}{c}\text { Powerful-Weak } \\
\text { Within Subj. Effects }\end{array}$} & \multicolumn{6}{|c|}{ Ventilation } & \multicolumn{6}{|c|}{ Air Conditioning } \\
\hline & SS & df & MS & $\mathbf{F}$ & $p$ & $\eta^{2} p$ & SS & df & MS & $\mathbf{F}$ & $p$ & $\eta^{2} p$ \\
\hline AFR & 502.59 & 3 & 167.53 & 337.29 & $<0.001$ & 0.899 & 458.49 & 3 & 152.83 & 233.30 & $<0.001$ & 0.860 \\
\hline AFR $\times$ Subj. Group & 3.56 & 3 & 1.19 & 2.39 & 0.072 & 0.059 & 1.14 & 3 & 0.38 & 0.58 & 0.631 & 0.015 \\
\hline Residual & 56.62 & 114 & 0.50 & & & & 74.68 & 114 & 0.66 & & & \\
\hline Eng. Type & 56.67 & 1 & 56.67 & 151.50 & $<0.001$ & 0.799 & 45.50 & 1 & 45.50 & 64.52 & $\begin{array}{c}< \\
0.001\end{array}$ & 0.629 \\
\hline $\begin{array}{l}\text { Eng. Type } \times \text { Subj. } \\
\text { Group }\end{array}$ & 0.17 & 1 & 0.17 & 0.45 & 0.507 & 0.012 & 0.01 & 1 & 0.01 & 0.01 & 0.930 & 0.000 \\
\hline Residual & 14.22 & 38 & 0.37 & & & & 26.80 & 38 & 0.71 & & & \\
\hline AFR $\times$ Eng. Type & 10.29 & 3 & 3.43 & 8.60 & $<0.001$ & 0.185 & 8.27 & 3 & 2.76 & 8.98 & $\begin{array}{c}< \\
0.001\end{array}$ & 0.191 \\
\hline $\begin{array}{l}\text { AFR } \times \text { Eng. Type } \times \\
\text { Subj. Group }\end{array}$ & 4.42 & 3 & 1.48 & 3.70 & 0.014 & 0.089 & 2.29 & 3 & 0.76 & 2.48 & 0.065 & 0.061 \\
\hline Residual & 45.45 & 114 & 0.40 & & & & 35.02 & 114 & 0.31 & & & \\
\hline Between Subj. Effects & SS & $\mathrm{df}$ & MS & $\mathrm{F}$ & $p$ & $\eta^{2} p$ & SS & Df & MS & $\mathrm{F}$ & $p$ & $\eta^{2} p$ \\
\hline Subj. Group & 4.20 & 1 & 4.20 & 3.40 & 0.073 & 0.082 & 2.69 & 1 & 2.69 & 2.73 & 0.107 & 0.067 \\
\hline Residual & 46.91 & 38 & 1.23 & & & & 37.45 & 38 & 0.98 & & & \\
\hline
\end{tabular}

Marginal means of the previous three adjective couples describing the Loudness dimension as a function of the Engine Type and Air Flow Rate are shown in Figure 1. Different graphs are shown for the Ventilation and Air Conditioning Functional Modality.

\section{Discussion}

In line with the literature $[29,30]$, previous research findings showed that $[23,24]$ Aesthetics and Loudness represent the two main dimensions describing the perception of HVAC noise inside car cabins. In this research, the three most representative adjective couples describing each dimension were considered.

For the Aesthetic dimension, the listening test results for the adjective couples of High Quality-Low Quality, Not Annoying-Annoying, and Unpleasant-Pleasant highlighted that the most relevant difference between the two Subject Groups occurred for High Quality-Low Quality. More specifically, the Japanese considered the quality of sounds to be significantly lower than Italians in both ICEVs and HEVs and whether the AC was turned on or off, but only at the highest air flow rates. The Not Annoying-Annoying item was found to be affected mainly by the airflow rates and the engine type, with ICEVs considered more annoying than HEVs, especially at low AFRs. Moreover, both the airflow rate and the type of engine showed interaction effects with the subject group in the Ventilation condition, with Japanese considering ICEVs more annoying. This interaction effect disappeared when the air conditioning was turned on. Furthermore, the results for "Unpleasant-Pleasant" also showed the main effects of the air flow rates and the engine type in influencing the evaluations. The higher the air flow rate, the more unpleasant the judgements. Both groups considered HEVs more pleasant.

For the Loudness dimension, Loud-Soft, Noisy-Quiet, and Powerful-Weak adjective couples were considered. For Loud-Soft, the air flow rates and type of engine affected the evaluations, whether with or without air conditioning on. In general, HEVs were considered softer then ICEVs but both were evaluated as loud as air flow rate increased. Regarding Noisy-Quiet, similar to the previous adjective couples, HEVs were considered quieter then ICEVs and both were evaluated as noisy as the air flow rate increased. Finally, considering the Powerful-Weak adjective couple, results showed the main effects of air flow rates and engine type in influencing the evaluations, with ICEVs considered significantly more powerful than HEVs by Japanese, especially at high air flow rates.

Although the Air Flow Rates of $75 \%$ and $100 \%$ were responsible for the general worsening in the Aesthetic and Loudness items for both groups, thus minimizing the 
positive effects of passing from ICEV to HEV, the findings suggests that Japanese market designers should control the effects of the high Air Flow Rates as much as possible, because they dramatically affect the perception of low quality and annoyance of the HVAC sound, more so than for Italians.

Although this research investigated the perception of HVACs' sound quality in several auditory scenarios-four Air Flow Rate levels, two Engine Type levels, and two Functional Modalities-per each Subject Group, their combination represents only some of the auditory scenarios that drivers and passengers may experience every day. In future, more realistic and complex operative conditions, which also consider the interactions among the HVAC systems, the cars operational conditions (i.e., driving speeds, urban vs. extraurban), and human habits and preferences (i.e., use of infotainment systems) should be investigated.

Author Contributions: Conceptualization, M.M. and K.Y.; methodology, M.M. and K.Y.; software, M.M., K.Y. and M.D.; validation, M.M., K.Y. and M.D.; formal analysis, F.C. and M.D.; investigation, F.C. and M.D.; resources, M.M. and K.Y.; data curation, F.C. and M.D.; writing-original draft preparation, F.C. and M.D.; writing — review and editing, M.M., L.M. and K.Y.; visualization, F.C.; supervision, L.M.; project administration, M.M. and K.Y. All authors have read and agreed to the published version of the manuscript.

Funding: This research received no external funding.

Institutional Review Board Statement: The study has been approved by the ethical committee of Department of Architecture and Industrial Design of the Università degli Studi della Campania "Luigi Vanvitelli".

Informed Consent Statement: Informed consent was obtained from all subjects involved in the study.

Acknowledgments: Authors want to thank all colleagues and friends who helped them to carry out the activities of the Collaborative Project "HVAC sound quality inside cars cabins" and who offered their time and vehicles for the measurements.

Conflicts of Interest: The authors declare no conflict of interest.

\section{References}

1. Genuit, K. The sound quality of vehicle interior noise: A challenge for the NVH-engineers. Int. J. Veh. Noise Vib. (IJVNV) 2004, 1, 158-168. [CrossRef]

2. Park, S.G.; Lee, H.J.; Bae, C.Y.; Lee, B.H.; Oh, J.E. The Standardization of Sound Quality Evaluation Method for the Vehicle Interior Noise. In Transactions of the Korean Society for Noise and Vibration Engineering; The Korean Society for Noise and Vibration Engineering: Jeju Island, Korea, 30 December 2007; pp. 1230-1237.

3. Lyon, R.H. Designing for Product Sound Quality; Marcel Dekker, Inc.: New York, NY, USA, 2000.

4. Pedersen, T.H.; Fog, C.L. Optimisation of perceived product quality. In Euronoise' 98; EAA: Oshkosh, WI, USA, 1998; pp. $633-638$.

5. Feldmann, C.; Carolus, T.; Schneider, M. A semantic differential for evaluating the sound quality of fan systems. In Proceedings of the ASME Turbo Expo 2017: Turbomachinery Technical Conference and Exposition. Vol. 1: Aircraft Engine; Fans and Blowers; Marine, Honors and Awards, Charlotte, NC, USA, 26-30 June 2017.

6. Altinsoy, M.E. Identification of quality attributes of automotive idle sounds and whole-body vibrations. Int. J. Vehicle Noise Vib. 2013, 9, 4-27. [CrossRef]

7. Li, D.; Huang, Y. The discomfort model of the micro commercial vehicles interior noise based on the sound quality analyses. Appl. Acoust. 2018, 132, 223-231. [CrossRef]

8. Brizon, C.J.D.S.; Medeiros, E.B. Combining subjective and objective assessments to improve acoustic comfort evaluation of motor cars. Appl. Acoust. 2012, 73, 913-920. [CrossRef]

9. Yoon, H.; Yang, I.H.; Jeong, J.E.; Park, S.G.; Oh, J.E. Reliability improvement of a sound quality index for a vehicle HVAC system using a regression and neural network model. Appl. Acoust. 2012, 73, 1099-1103. [CrossRef]

10. Leite, R.P.; Paul, S.; Gerges, S.N. A sound quality-based investigation of the HVAC system noise of an automobile model. Appl. Acoust. 2009, 70, 636-645. [CrossRef]

11. Naji, S.; Ailloud, F. Automotive HVAC Unit Noise Prediction Using Blower Dimensioning Tool. In Proceedings of the International Conference on Automotive and Railroad Comfort, Le Mans, France, 17-18 October 2008.

12. Nagarhalli, P.; Maurya, A.; Kalsule, S.; Titave, U. Optimizing an Automotive HVAC System for Enhancement of Acoustic Comfort. In Thermal Management Systems Conference 2021; SAE Technical Paper 2021-28-0147; SAE: Warrendale, PA, USA, 2021. 
13. Bennouna, S.; Matharan, T.; Cheriaux, O. Automotive HVAC Noise Reduction. In 10th International Styrian Noise, Vibration E Harshness Congress: The European Automotive Noise Conference; SAE Technical Paper 2018-01-1519; SAE: Warrendale, PA, USA, 2018.

14. Ene, A.; Catalina, T.; Vartires, A. Determination of thermal and acoustic comfort inside a vehicle's cabin. E3S Web Conf. 2018, 32, 01002. [CrossRef]

15. Electric Surge: Carmakers' Electric Car Plan across Europe 2019-2025. Transport \& Environment. European Federation for Transport and Environment. Figure 11 EU Production of Vehicles per Type in 2025. July 2019. Available online: https: / / www.transportenvironment.org/discover/electric-surge-carmakers-electric-car-plans-across-europe-2019-2025/ (accessed on 25 November 2021).

16. Masullo, M.; Yamauchi, K.; Nakatani, Y.; Maffei, L. HVAC noise perception in car cabin: A preliminary comparison between ICEVs and HEVs. In Proceedings of the 23rd International Congress on Acoustics, ICA 2019, Aachen, Germany, 9-13 September 2019.

17. Graham-Rowe, E.; Gardner, B.; Abraham, C.; Skippon, S.; Dittmar, H.; Hutchins, R.; Stannard, J. Mainstream consumers driving plug-in battery-electric and plug-in hybrid electric cars: A qualitative analysis of responses and evaluations. Transp. Res. Part A Policy Pract. 2012, 46, 140-153. [CrossRef]

18. Cocron, P.; Bühler, F.; Franke, T.; Neumann, I.; Krems, J.F. The silence of electric vehicles-blessing or curse. In Proceedings of the 90th Annual Meeting of the Transportation Research Board, Washington, DC, USA, 23-27 January 2011.

19. Münder, M.; Carbon Howl, C.C. Whirr, and whistle: The perception of electric powertrain noise and its importance for perceived quality in electrified vehicles. Appl. Acoust. 2022, 185, 108412. [CrossRef]

20. Krishna, G. Understanding and identifying barriers to electric vehicle adoption through thematic analysis. Transp. Res. Interdiscip. Perspect. 2021, 10, 100364. [CrossRef]

21. Kuwano, S.; Fastl, H.; Namba, S.; Nakamura, S.; Uchida, H. Quality of door sounds of passenger cars. Acoust. Sci. Technol. 2006, 27, 309-312. [CrossRef]

22. Kuwano, S.; Namba, S.; Hato, T.; Matui, M.; Miura, K.; Imai, H. Psychological Evaluation of Noise in Passenger Cars: Analysis in Different Group of Subjects in Nationality, Age and Gender. In Contributions to Psychological Acoustics; Schick, A., Ed.; Results of the Sixth Oldenburg Symposium on Psychological Acoustics; BIS: Oldenburg, Germany, 1993; pp. 521-536.

23. Dan, M.; Yamauchi, K.; Cioffi, F.; Maffei, L.; Masullo, M. Comparison of HVAC Sound Quality between ICEVs and EVs. 2021. Available online: https:/ / internoise2021.org/abstract/perceptual-difference-on-hvac-sound-quality-between-electricand-conventional-vehicles / (accessed on 25 November 2021).

24. Yamauchi, K.; Dan, M.; Cioffi, F.; Maffei, L.; Masullo, M. Perceptual Difference on HVAC Sound Quality between Electric and Conventional Vehicles. In Proceedings of the Internoise 2021, Washington, DC, USA, 1-5 August 2021.

25. Nakasaki, R.; Ogata, T.; Hasegawa, H.; Ozeki, Y.; Onda, M.; Kasuga, M. Sound quality evaluation of air-conditioning sounds in a vehicle using psychoacoustic parameters. J. Acoust. Soc. Am. 2008, 123, 3533. [CrossRef]

26. Nakasaki, R.; Hasegawa, H.; Kasuga, M. Evaluation of air-conditioning sounds in a vehicle to determine thermal feelings using psychoacoustic parameters. Acoust. Sci. Technol. 2013, 34, 159-165. [CrossRef]

27. Park, S.-G.; Sim, H.-J.; Yoon, J.-H.; Jeong, J.-E.; Choi, B.-J.; Oh, J.-E. Analysis of the HVAC system's sound quality using the design of experiments. J. Mech. Sci. Technol. 2009, 23, 2801-2806. [CrossRef]

28. Minard, A.; Lambourg, C.; Boussard, P. Perceptual evaluation of the sound quality of car HVAC systems. In Proceedings of the Internoise 2014, Hamburg, Germany, 21-24 August 2014.

29. Wagner, V.; Enigk, H.; Beitz, T.; Kallus, K.W. Subjective and Objective Evaluation of the Air Conditioning Sound. J. Ergon. 2014, 4, 131.

30. Jennings, P.A.; Dunne, G.; Williams, R.; Giudice, S. Tools and techniques for understanding the fundamentals of automotive sound quality. Proc. Inst. Mech. Eng. Part D J. Automob. Eng. 2010, 224, 1263-1278. [CrossRef] 